\title{
Reclassification of [Cytophaga] marinoflava Reichenbach 1989 as Leeuwenhoekiella marinoflava gen. nov., comb. nov. and description of Leeuwenhoekiella aequorea sp. nov.
}

\author{
Olga I. Nedashkovskaya, ${ }^{1}$ Marc Vancanneyt, ${ }^{2}$ P. Dawyndt, ${ }^{3}$ \\ Katrien Engelbeen, ${ }^{2}$ Katrien Vandemeulebroecke, ${ }^{2}$ Ilse Cleenwerck, ${ }^{2}$ \\ Bart Hoste, ${ }^{2}$ Joris Mergaert, ${ }^{3}$ Tjhing-Lok Tan, ${ }^{4}$ Galina M. Frolova,${ }^{1}$ \\ Valery V. Mikhailov ${ }^{1}$ and Jean Swings $s^{2,3}$
}

Correspondence

Olga I. Nedashkovskaya olganedashkovska@yahoo.com
${ }^{1}$ Pacific Institute of Bioorganic Chemistry of the Far-Eastern Branch of the Russian Academy of Sciences, Pr. 100 Let Vladivostoku 159, 690022, Vladivostok, Russia

${ }^{2,3}$ BCCM/LMG Bacteria Collection ${ }^{2}$ and Laboratory of Microbiology ${ }^{3}$, Ghent University, Ledeganckstraat 35, B-9000 Ghent, Belgium

${ }^{4}$ Alfred-Wegener-Institüt für Polar- und Meeresforschung, Am Handelshfen 12, D-27570 Bremerhaven, Germany

Five heterotrophic, aerobic, halotolerant and pigmented bacterial strains with gliding motility were isolated from Antarctic sea water; one other isolate was collected from the sea urchin Strongylocentrotus intermedius in the Gulf of Peter the Great in the Sea of Japan. 16S rRNA gene sequence analysis indicated that the strains are members of the family Flavobacteriaceae, the nearest neighbour (with 97.1\% sequence similarity) being the misclassified species [Cytophaga] marinoflava. DNA-DNA hybridization experiments and chemotaxonomic and phenotypic analyses demonstrated that the six novel isolates represent a single species distinct from [C.] marinoflava. On the basis of its separate phylogenetic lineage (the nearest neighbours show $92 \%$ sequence similarity), [C.] marinoflava is reclassified as Leeuwenhoekiella marinoflava gen. nov., comb. nov. A second species of this new genus, Leeuwenhoekiella aequorea sp. nov., is proposed for the six novel isolates, with strain LMG 22550 ${ }^{\top}$ (=CCUG $50091^{\top}$ ) as the type strain.
Many novel taxa that inhabit shallow-water environments have been described within the family Flavobacteriaceae in recent years (Bernardet et al., 2002). Most coastal-water flavobacteria, e.g. members of the genera Arenibacter, Cellulophaga, Gelidibacter, Mesonia, Muricauda, Polaribacter, Psychroserpens, Tenacibaculum, Ulvibacter, Vitellibacter and Zobellia, require $\mathrm{NaCl}$ or sea water for growth and are described as weakly or moderately halophilic (Kushner, 1978; Reichenbach, 1989; Bowman et al., 1997; Gosink et al., 1998; Johansen et al., 1999; Barbeyron et al., 2001; Bruns et al., 2001; Ivanova et al., 2001; Suzuki et al., 2001; Nedashkovskaya et al., 2003b, d, 2004a). The halotolerant taxa of the family Flavobacteriaceae, e.g. Salegentibacter salegens and Psychroflexus gondwanensis, can grow without $\mathrm{Na}^{+}$ions or sea water and can tolerate high salinity levels

Published online ahead of print on 25 November 2004 as DOI 10.1099/ijs.0.63410-0.

The GenBank/EMBL/DDBJ accession numbers for the 16S rRNA gene sequences of Leeuwenhoekiella aequorea strains LMG $22550^{\top}$ and KMM 6066 are AJ278780 and AJ780980, respectively.
(Dobson et al., 1993; McCammon \& Bowman, 2000; Bowman et al., 1998).

The genus Cytophaga was established by Winogradsky (1929) and emended by Reichenbach (1989). Later, Nakagawa \& Yamasato (1996) proposed the restriction of this genus on the basis of 16S rRNA gene sequence phylogenetic analysis, and emended the genus description. Currently, the genus Cytophaga sensu stricto (aerobic, gliding, pigmented, cellulose-degrading bacteria) comprises two species: Cytophaga aurantiaca and Cytophaga hutchinsonii. Some marine bacteria previously included in the genus Cytophaga have been reclassified (Nakagawa \& Yamasato, 1996; Nakagawa et al., 1997; Johansen et al., 1999; Suzuki et al., 2001; Barbeyron et al., 2001; Nedashkovskaya et al., 2005). At present, two misnamed species of the genus Cytophaga that were isolated from marine environments, [Cytophaga] fermentans and [Cytophaga] marinoflava, remain to be reclassified.

In this work, we report the isolation and identification of six novel halotolerant, Gram-negative, aerobic, gliding, 
yellow-pigmented marine bacteria. On the basis of the results of genotypic, chemotaxonomic and phenotypic analyses, it is clear that the isolates represent a novel species, with [C.] marinoflava as the nearest neighbour. Both taxa are here classified in a single novel genus, as Leeuwenhoekiella marinoflava gen. nov., comb. nov. and Leeuwenhoekiella aequorea sp. nov.

Strains LMG $22550^{\mathrm{T}}$ (=ANT $14^{\mathrm{T}}$ ), LMG 22551 (=ANT 18d/2), LMG 22552 (=ANT 26b), LMG 22553 (=ANT 35/ 2) and LMG 22554 (=ANT 54b/2) were isolated previously from Antarctic sea-water samples at stations above Gunnerus Ridge and Astrid Ridge (Tan et al., 1999), using enrichment in dialysis chambers (Tan, 1997). Strain KMM 6066 (=LMG 22555) was isolated from the sea urchin Strongylocentrotus intermedius in Troitsa Bay, Gulf of Peter the Great, Sea of Japan. For the isolation of the latter strain, $0 \cdot 1 \mathrm{ml}$ tissue homogenate was transferred onto plates of marine agar 2216 (Difco). After primary isolation and purification, strains were cultivated at $28{ }^{\circ} \mathrm{C}$ on the same medium and stored at $-80^{\circ} \mathrm{C}$ in marine broth 2216 (Difco) supplemented with $20 \%(\mathrm{v} / \mathrm{v})$ glycerol.

An almost-complete $16 \mathrm{~S}$ rRNA gene sequence (1475 nt) of one representative of the Antarctic isolates, strain LMG $22550^{\mathrm{T}}$, was determined previously in a study on the diversity of facultative oligotrophic bacteria from polar seas (Mergaert et al., 2001). The sequence of strain KMM 6066 (1474 nt) was determined in the present study by following a procedure described previously (Vancanneyt et al., 2004) and showed a similarity of $99 \cdot 8 \%$ with respect to LMG $22550^{\mathrm{T}}$. The nearest phylogenetic neighbour of both strains was [C.] marinoflava ATCC $19326^{\mathrm{T}}$ (=LMG $\left.1345^{\mathrm{T}}\right)$ : the $16 \mathrm{~S}$ rRNA gene sequence similarity was $97 \cdot 1 \%$. The three strains formed a distinct lineage within the family Flavobacteriaceae, showing sequence similarity levels below $92 \cdot 2 \%$ with the genera Vitellibacter, Aequorivita, Arenibacter, Muricauda, Zobellia and Maribacter (Fig. 1). These observations allow reclassification of members of the [C.] marinoflava branch within a novel genus.
DNA $\mathrm{G}+\mathrm{C}$ contents were determined for strains $\mathrm{LMG}$ $22550^{\mathrm{T}}$ to LMG 22555 and for [C.] marinoflava LMG $1345^{\mathrm{T}}$. Strains were cultivated on marine agar 2216 for $24 \mathrm{~h}$ at $37^{\circ} \mathrm{C}$. DNA was extracted from $0 \cdot 75-1 \cdot 25 \mathrm{~g}$ (wet wt) cells, using the DNA extraction protocol of Wilson (1987) as modified by Cleenwerck et al. (2002). Cells were lysed in a Tris/EDTA buffer (10 mM Tris/HCl with up to $200 \mathrm{mM}$ EDTA, pH 8.0) containing RNase A (Sigma), SDS (Serva) and proteinase $\mathrm{K}$ (Merck) to final concentrations of $400 \mu \mathrm{g} \mathrm{ml}^{-1}, 2 \%(\mathrm{w} / \mathrm{v})$ and $200 \mu \mathrm{g} \mathrm{ml}^{-1}$, respectively. $\mathrm{NaCl}$ (5 $\mathrm{M}$ stock solution) and $\mathrm{CTAB} / \mathrm{NaCl}$ solution $(10 \%$, $\mathrm{w} / \mathrm{v}$, hexadecyltrimethylammonium bromide in $0.7 \mathrm{M}$ $\mathrm{NaCl}$ ) were added to final concentrations of $1 \mathrm{M}$ and $13 \cdot 3 \%(\mathrm{v} / \mathrm{v})$, respectively. For determination of $\mathrm{G}+\mathrm{C}$ content, DNA was enzymically degraded into nucleosides as described by Mesbah et al. (1989). The nucleoside mixture obtained was then separated by HPLC using a Waters Symmetry Shield $\mathrm{C} 8$ column maintained at a temperature of $37^{\circ} \mathrm{C}$. The solvent was $0.02 \mathrm{M} \mathrm{NH}_{4} \mathrm{H}_{2} \mathrm{PO}_{4}(\mathrm{pH} 4 \cdot 0$ ) with $1.5 \%$ acetonitrile. Non-methylated phage $\lambda$ DNA (Sigma) was used as the calibration reference.

The DNA G + C contents were $35-36 \mathrm{~mol} \%$ for the novel isolates (LMG $22550^{\mathrm{T}}$ to LMG 22555) and $38 \mathrm{~mol} \%$ for the type strain of [C.] marinoflava (LMG $1345^{\mathrm{T}}$ ). DNADNA hybridizations were performed between strains LMG $22550^{\mathrm{T}}$ to LMG 22555 and [C.] marinoflava LMG $1345^{\mathrm{T}}$ with DNA prepared as described above. The microplate method was used as described by Ezaki et al. (1989) and Goris et al. (1998), using an HTS7000 Bio Assay Reader (Perkin Elmer) for the fluorescence measurements. Biotinylated DNA was hybridized with single-stranded unlabelled DNA, non-covalently bound to microplate wells. Hybridizations were performed at $36^{\circ} \mathrm{C}$ in a hybridization mixture $[2 \times$ SSC, $5 \times$ Denhardt's solution, $2 \cdot 5 \%$ dextran sulphate, $50 \%$ formamide, $100 \mu \mathrm{g}$ denatured low-molecular-mass salmon sperm DNA ml ${ }^{-1}, 1250 \mathrm{ng}$ biotinylated probe DNA $\mathrm{ml}^{-1}$ ]. Hybridization levels of $79-100 \%$ were found between strains LMG $22550^{\mathrm{T}}$ to LMG

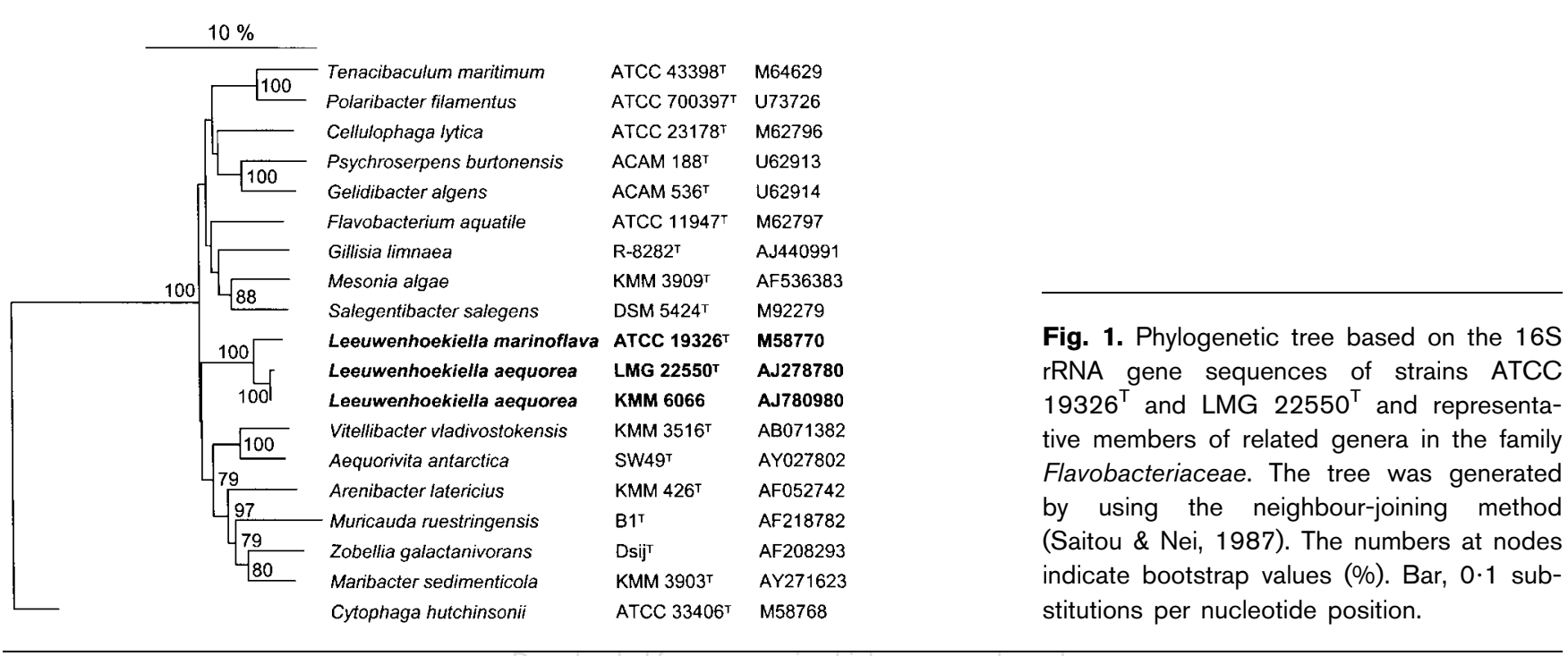


22555, which indicates that the strains constitute a single species. The latter strains had binding values of 9-14\% with [C.] marinoflava LMG $1345^{\mathrm{T}}$. These data indicate that the novel isolates constitute a single species distinct from the latter misclassified species (Wayne et al., 1987).

The analysis of fatty acid methyl esters was carried out according to the standard protocol of the Microbial Identification System (Microbial ID). The main cellular fatty acids of the strains studied were 15:0 iso, $15: 1$ iso G, $17: 0$ iso $3-\mathrm{OH}$, iso $17: 1 \omega 9 c$ and summed feature 3 (see Table 1). [C.] marinoflava is distinguished from the novel isolates by a significantly larger amount of $17: 0$ iso $3-\mathrm{OH}$ and smaller amount of iso $17: 1 \omega 9 c$. Furthermore, the presence of minor amounts of 15:03-OH and the absence of anteiso $17: 1 \omega 9 c$ and summed feature 4 (Table 1) fatty acids in the [C.] marinoflava whole-cell fatty acid profile support its differentiation from strains LMG $22550^{\mathrm{T}}$ to LMG 22555. Isoprenoid quinones were extracted from lyophilized cells and analysed as described previously (Nedashkovskaya et al., 2003d). The major respiratory quinone was MK-6.

Table 1. Fatty acid content (mean percentage of total) of members of the genus Leeuwenhoekiella gen. nov.

Those fatty acids for which the amount (for all taxa) is less than $1 \%$ are not given. tr, Trace amount (less than $1 \%$ ); number of strains studied.

\begin{tabular}{|lcc|}
\hline Fatty acid & $\begin{array}{c}\text { L. aequorea } \\
(\boldsymbol{n}=\mathbf{6})\end{array}$ & $\begin{array}{c}\text { L. marinoflava } \\
\text { LMG } \mathbf{1 3 4 5}^{\mathbf{T}}\end{array}$ \\
\hline $15: 0$ 2-OH & $1 \cdot 2 \pm 0 \cdot 2$ & $1 \cdot 4$ \\
$15: 0$ 3-OH & - & $1 \cdot 3$ \\
$15: 0$ anteiso & $4 \cdot 5 \pm 0 \cdot 4$ & $2 \cdot 7$ \\
$15: 0$ iso & $18 \cdot 2 \pm 1 \cdot 1$ & $16 \cdot 0$ \\
$15: 1$ iso G & $7 \cdot 6 \pm 1 \cdot 6$ & $10 \cdot 4$ \\
$15: 0$ iso 3-OH & $2 \cdot 1 \pm 0 \cdot 2$ & $3 \cdot 9$ \\
$16: 0$ iso & $3 \cdot 8 \pm 1 \cdot 2$ & $1 \cdot 1$ \\
$16: 1$ iso H & $1 \cdot 4 \pm 0 \cdot 4$ & $\operatorname{tr}$ \\
$16: 0$ iso 3-OH & $3 \cdot 4 \pm 0 \cdot 9$ & $2 \cdot 5$ \\
$17: 0$ 2-OH & $4 \cdot 2 \pm 0 \cdot 6$ & $4 \cdot 4$ \\
$17: 0$ iso 3-OH & $12 \cdot 7 \pm 1 \cdot 0$ & $22 \cdot 1$ \\
$17: 1 \omega 6 c$ & $2 \cdot 1 \pm 0 \cdot 4$ & $1 \cdot 8$ \\
$17: 1 \omega 8 c$ & $\operatorname{tr}$ & $1 \cdot 3$ \\
anteiso $17: 1 \omega 9 c$ & $1 \cdot 6 \pm 0 \cdot 4$ & - \\
iso $17: 1 \omega 9 c$ & $18 \cdot 8 \pm 2 \cdot 9$ & $12 \cdot 1$ \\
Summed feature $3 *$ & $9 \cdot 4 \pm 1 \cdot 6$ & $10 \cdot 9$ \\
Summed feature $4^{*}$ & $1 \cdot 3 \pm 0 \cdot 2$ & - \\
ECL $13 \cdot 565 \dagger$ & $\operatorname{tr}$ & $1 \cdot 3$ \\
ECL $16 \cdot 582 \dagger$ & $\operatorname{tr}$ & $1 \cdot 2$ \\
& & \\
\hline
\end{tabular}

*Summed features consist of one or more fatty acids that could not be separated by the Microbial Identification System. Summed feature 3: $15: 0$ iso $2-\mathrm{OH}, 16: 1 \omega 7 c$ and/or $16: 1 \omega 7 t$. Summed feature 4: $17: 1$ iso I and/or $17: 1$ anteiso $B$.

$\dagger$ Unidentified fatty acids (ECL, equivalent chain length).
Phenotypic analysis was performed by using previously described methods (Nedashkovskaya et al., 2003a, b). The physiological, biochemical and morphological characteristics of the strains studied are listed in the species description and in Table 2. The results of phenotypic examination of the strains studied, including the ability of strains LMG $22550^{\mathrm{T}}$ to LMG 22555 to form acid from D-sucrose and mannitol and to utilize mannitol, in combination with the molecular distinctiveness allow the differentiation of strains LMG $22550^{\mathrm{T}}$ to LMG 22555 from their closest relative, [C.] marinoflava, at the species level. However, on the basis of the phenotypic analysis, the cellular fatty acid composition and the phylogenetic positions of the strains examined, we propose that LMG $22550^{\mathrm{T}}$ to LMG 22555 and [C.] marinoflava LMG $1345^{\mathrm{T}}$ represent two distinct species of the same novel genus. The main phenotypic characteristics that differentiate the strains studied from other relatives in the family Flavobacteriaceae are listed in Table 2.

We conclude that the bacteria studied could not be assigned to any of the existing genera or species currently included in the family Flavobacteriaceae. Consequently, we propose that strains LMG $22550^{\mathrm{T}}$ to LMG 22555 be placed in a novel genus, Leeuwenhoekiella gen. nov., as Leeuwenhoekiella aequorea sp. nov., and that [C.] marinoflava be reclassified as Leeuwenhoekiella marinoflava comb. nov.

\section{Description of Leeuwenhoekiella gen. nov.}

Leeuwenhoekiella [Leeu.wen.hoe.ki.el'la. N.L. fem. dim. n. Leeuwenhoekiella of Leeuwenhoek, named in honour of the famous Dutchman Antonie van Leeuwenhoek (16321723), discoverer of micro-organisms].

Rod-shaped cells, motile by gliding. Gram-negative. Endospores are not formed. Strictly aerobic. Produces nondiffusible yellow pigments. No flexirubins are formed. Chemo-organotrophic. Cytochrome oxidase-, catalase-, $\beta$-galactosidase- and alkaline phosphatase-positive. The major respiratory quinone is MK-6. The dominant cellular fatty acids $(>5 \%)$ are 15:0 iso, $15: 1$ iso $G, 17: 0$ iso $3-\mathrm{OH}$, iso $17: 1 \omega 9 \mathrm{c}$ and summed feature 3 (see Table 1 ). According to $16 \mathrm{~S}$ rRNA gene sequence phylogenetic analysis, the genus Leeuwenhoekiella is a member of the family Flavobacteriaceae. The type species is Leeuwenhoekiella marinoflava.

\section{Description of Leeuwenhoekiella marinoflava comb. nov.}

Leeuwenhoekiella marinoflava (ma.ri.no.fla'va. L. adj. marinus marine; L. adj. flavus golden yellow; N.L. fem. adj. marinoflava marine and yellow-pigmented).

Basonym: Cytophaga marinoflava (ex Colwell et al. 1966) Reichenbach 1989.

The main characteristics are those as given for the genus and by Reichenbach (1989). In addition, growth is observed at $4-37^{\circ} \mathrm{C}$. Optimal temperature for growth is $21-23^{\circ} \mathrm{C}$. 
Table 2. Differential characteristics of the genus Leeuwenhoekiella and other related genera of the family Flavobacteriaceae

Genera: 1, Leeuwenhoekiella gen. nov.; 2, Arenibacter; 3, Zobellia; 4, Muricauda; 5, Vitellibacter; 6, Aequorivita; 7, Maribacter. Data were taken from Barbeyron et al. (2001), Bruns et al. (2001), Ivanova et al. (2001), Bowman \& Nichols (2002), Nedashkovskaya et al. (2003b, c, 2004b, c) and this study. Abbreviations: -, negative; +, positive; V, variable; ND, not determined.

\begin{tabular}{|c|c|c|c|c|c|c|c|}
\hline Characteristic & 1 & 2 & 3 & 4 & 5 & 6 & 7 \\
\hline Anaerobic growth & - & - & - & + & - & - & - \\
\hline Gliding motility & + & - & + & + & - & - & + \\
\hline Oxidase/catalase & $+1+$ & $+1+$ & $+1+$ & $+1-$ & $+/+$ & $-1+$ & $+/+$ \\
\hline Flexirubin pigments & - & - & + & - & + & - & - \\
\hline Requirement for $\mathrm{Na}^{+}$for growth & - & + & + & + & + & $\mathrm{V}$ & + \\
\hline Acid formation from carbohydrates & + & + & + & $\mathrm{ND}$ & - & - & $\mathrm{V}$ \\
\hline \multicolumn{8}{|l|}{ Growth at/in: } \\
\hline $37^{\circ} \mathrm{C}$ & + & + & $\mathrm{v}$ & + & + & - & - \\
\hline $42^{\circ} \mathrm{C}$ & - & $\mathrm{V}$ & $\mathrm{v}$ & - & + & - & - \\
\hline $15 \% \mathrm{NaCl}$ & + & - & - & - & - & - & - \\
\hline \multicolumn{8}{|l|}{ Hydrolysis of: } \\
\hline Agar & - & - & + & - & - & - & $\mathrm{V}$ \\
\hline Casein & + & - & $\mathrm{V}$ & $\mathrm{ND}$ & + & $\mathrm{V}$ & - \\
\hline Gelatin & + & $\mathrm{V}$ & + & - & + & + & $\mathrm{V}$ \\
\hline Starch & + & - & $\mathrm{V}$ & - & - & - & $\mathrm{V}$ \\
\hline DNA & - & $\mathrm{V}$ & $\mathrm{v}$ & $\mathrm{ND}$ & + & - & $\mathrm{V}$ \\
\hline Nitrate reduction & - & + & + & - & - & - & $\mathrm{V}$ \\
\hline DNA G $+C$ content $(\mathrm{mol} \%)$ & $35-38$ & $37-40$ & $36-44$ & 41 & 41 & $33-39$ & $35-39$ \\
\hline
\end{tabular}

Growth occurs at $0-15 \% \mathrm{NaCl}$, with optimal growth at $1-3 \% \mathrm{NaCl}$. Nitrate is not reduced. Indole, $\mathrm{H}_{2} \mathrm{~S}$ and acetoin (Voges-Proskauer reaction) are not produced. Decomposes casein, gelatin, Tweens 20, 40 and 80 and starch. Does not hydrolyse DNA, urea, cellulose (CMcellulose and filter paper) or chitin. Forms acid from D-galactose and glycerol, but not from L-arabinose, Dcellobiose, L-fucose, D-glucose, D-lactose, D-maltose, Dmelibiose, L-raffinose, L-rhamnose, L-sorbose, D-sucrose, D-trehalose, DL-xylose, $\mathrm{N}$-acetylglucosamine, citrate, acetate, fumarate, malate, adonitol, dulcitol, inositol or mannitol. Utilizes L-arabinose, D-glucose, D-lactose, D-mannose and D-sucrose, but not inositol, sorbitol, mannitol, malonate or citrate. Susceptible to benzylpenicillin, carbenicillin, lincomycin, doxycycline, erythromycin and chloramphenicol. The $\mathrm{G}+\mathrm{C}$ content of the DNA is $38 \mathrm{~mol} \%$.

The type strain is LMG $1345^{\mathrm{T}}$ (=ATCC $19326^{\mathrm{T}}$ ). Isolated from sea water collected in the North Sea off Aberdeen, Scotland, UK.

\section{Description of Leeuwenhoekiella aequorea sp. nov.}

Leeuwenhoekiella aequorea (ae.quo.re' a. L. fem. adj. aequorea of the sea, marine).

The main characteristics are as given for the genus. In addition, cells range from 0.5 to $0.6 \mu \mathrm{m}$ in width and from $1 \cdot 6$ to $2 \cdot 3 \mu \mathrm{m}$ in length. On marine agar 2216 , colonies are
2-4 $\mathrm{mm}$ in diameter, circular with entire edges and bright yellow in colour. Growth is observed at $4-37^{\circ} \mathrm{C}$. Optimal temperature for growth is $23-25^{\circ} \mathrm{C}$. Growth occurs at $0-15 \% \mathrm{NaCl}$, with optimal growth at $0-5 \% \mathrm{NaCl}$. Nitrate is not reduced. Indole, $\mathrm{H}_{2} \mathrm{~S}$ and acetoin (Voges-Proskauer reaction) are not produced. Decomposes casein, gelatin, starch and Tweens 20, 40 and 80. Does not hydrolyse agar, DNA, urea, cellulose (CM-cellulose and filter paper) or chitin. Forms acid from D-galactose, D-sucrose, glycerol and mannitol, but not from L-arabinose, D-cellobiose, L-fucose, D-glucose, D-lactose, D-maltose, D-melibiose, Lraffinose, L-rhamnose, L-sorbose, DL-xylose, $\mathrm{N}$-acetylglucosamine, acetate, citrate, fumarate, malate, adonitol, dulcitol or inositol. Can oxidize D-trehalose. Utilizes L-arabinose, D-glucose, D-lactose, D-mannose, D-sucrose and mannitol, but not inositol, sorbitol, malonate or citrate. The $\mathrm{G}+\mathrm{C}$ content of the DNA is $35-36 \mathrm{~mol} \%$.

The type strain is LMG $22550^{\mathrm{T}}$ (=CCUG $50091^{\mathrm{T}}$ ), which was isolated from Antarctic sea water. Strain LMG 22555 was isolated from the sea urchin Strongylocentrotus intermedius found in the Sea of Japan.

\section{Acknowledgements}

This research was supported by grants from the Federal Agency for Sciences and Innovations of the Ministry for Education and Sciences of the Russian Federation (no. 2-2.16), the Russian Foundation for Basic Research (no. 05-04-48211) and the Program of Fundamental Investigations of the Presidium of the Russian Academy of Sciences 'Molecular and Cell Biology'. 


\section{References}

Barbeyron, T., L'Haridon, S., Corre, E., Kloareg, B. \& Potin, P. (2001). Zobellia galactanovorans gen. nov., sp. nov., a marine species of Flavobacteriaceae isolated from a red alga, and classification of [Cytophaga] uliginosa (ZoBell and Upham 1944) Reichenbach 1989 as Zobellia uliginosa gen. nov., comb. nov. Int J Syst Evol Microbiol 51, 985-997.

Bernardet, J.-F., Nakagawa, Y. \& Holmes, B. (2002). Proposed minimal standards for describing new taxa of the family Flavobacteriaceae and emended description of the family. Int J Syst Evol Microbiol 52, 1049-1070.

Bowman, J. P. \& Nichols, D. S. (2002). Aequorivita gen. nov., a member of the family Flavobacteriaceae isolated from terrestrial and marine Antarctic habitats. Int J Syst Evol Microbiol 52, 1533-1541.

Bowman, J. P., McCammon, S. A., Brown, J. L., Nichols, P. D. \& McMeekin, T. A. (1997). Psychroserpens burtonensis gen. nov., sp. nov., and Gelidibacter algens gen. nov., sp. nov., psychrophilic bacteria isolated from Antarctic lacustrine and sea ice habitats. Int J Syst Bacteriol 47, 670-677.

Bowman, J. P., McCammon, S. A., Lewis, T., Skerratt, J. H., Brown, J. L., Nichols, D. S. \& McMeekin, T. A. (1998). Psychroflexus torquis gen. nov., sp. nov., a psychrophilic species from Antarctic sea ice, and reclassification of Flavobacterium gondwanense (Dobson et al. 1993) as Psychroflexus gondwanense gen. nov., comb. nov. Microbiology 144, 1601-1609.

Bruns, A., Rohde, M. \& Berthe-Corti, L. (2001). Muricauda ruestringensis gen. nov., sp. nov., a facultatively anaerobic, appendaged bacterium from German North Sea intertidal sediment. Int J Syst Evol Microbiol 51, 1997-2006.

Cleenwerck, I., Vandemeulebroecke, K., Janssens, D. \& Swings, J. (2002). Re-examination of the genus Acetobacter, with descriptions of Acetobacter cerevisiae sp. nov. and Acetobacter malorum sp. nov. Int J Syst Evol Microbiol 52, 1551-1558.

Dobson, S. J., Colwell, R. R., McMeekin, T. A. \& Franzmann, P. D. (1993). Direct sequencing of the polymerase chain reaction-amplified $16 \mathrm{~S}$ rRNA gene of Flavobacterium gondwanense sp. nov. and Flavobacterium salegens sp. nov., two new species from a hypersaline Antarctic lake. Int J Syst Bacteriol 43, 77-83.

Ezaki, T., Hashimoto, Y. \& Yabuuchi, E. (1989). Fluorometric deoxyribonucleic acid-deoxyribonucleic acid hybridization in microdilution wells as an alternative to membrane filter hybridization in which radioisotopes are used to determine genetic relatedness among bacterial strains. Int J Syst Bacteriol 39, 224-229.

Goris, J., Suzuki, K., De Vos, P., Nakase, T. \& Kersters, K. (1998). Evaluation of a microplate DNA-DNA hybridization method compared with the initial renaturation method. Can J Microbiol 44, 1148-1153.

Gosink, J. J., Woese, C. R. \& Staley, J. T. (1998). Polaribacter gen. nov., with three new species, $P$. irgensii sp. nov., $P$. franzmannii sp. nov. and $P$. filamentus sp. nov., gas vacuolate polar marine bacteria of the Cytophaga-Flavobacterium-Bacteroides group and reclassification of 'Flectobacillus glomeratus' as Polaribacter glomeratus comb. nov. Int J Syst Bacteriol 48, 223-235.

Ivanova, E. P., Nedashkovskaya, O. I., Chun, J. \& 7 other authors (2001). Arenibacter gen. nov., a new genus of the family Flavobacteriaceae and description of a new species, Arenibacter latericius sp. nov. Int J Syst Evol Microbiol 51, 1987-1995.

Johansen, J. E., Nielsen, P. \& Sjøholm, C. (1999). Description of Cellulophaga baltica gen. nov., sp. nov. and Cellulophaga fucicola gen. nov., sp. nov. and reclassification of [Cytophaga] lytica to Cellulophaga lytica gen. nov., comb. nov. Int J Syst Bacteriol 49, 1231-1240.
Kushner, D. J. (1978). Life in high salt and solute concentrations: halophilic bacteria. In Microbial Life in Extreme Environments. Edited by D. J. Kushner. London: Academic Press.

McCammon, S. A. \& Bowman, J. P. (2000). Taxonomy of Antarctic Flavobacterium species: description of Flavobacterium gillisiae sp. nov., Flavobacterium tegetincola sp. nov. and Flavobacterium xanthum sp. nov., nom. rev., and reclassification of [Flavobacterium] salegens as Salegentibacter salegens gen. nov., comb. nov. Int J Syst Evol Microbiol 50, 1055-1063.

Mergaert, J., Verhelst, A., Cnockaert, M. C., Tan, T. L. \& Swings, J. (2001). Characterization of facultative oligotrophic bacteria from polar seas by analysis of their fatty acids and $16 \mathrm{~S}$ rDNA sequences. Syst Appl Microbiol 24, 98-107.

Mesbah, M., Premachandran, U. \& Whitman, W. B. (1989). Precise measurement of the $\mathrm{G}+\mathrm{C}$ content of deoxyribonucleic acid by high-performance liquid chromatography. Int J Syst Bacteriol 39, 159-167.

Nakagawa, Y. \& Yamasato, K. (1996). Emendation of the genus Cytophaga and transfer of Cytophaga agarovorans and Cytophaga salmonicolor to Marinilabilia gen. nov.: phylogenetic analysis of the Flavobacterium-Cytophaga complex. Int J Syst Bacteriol 46, 599-603.

Nakagawa, Y., Hamana, K., Sakane, T. \& Yamasato, K. (1997). Reclassification of Cytophaga aprica (Lewin 1969) Reichenbach 1989 in Flammeovirga gen. nov. as Flammeovirga aprica comb. nov. and Cytophaga diffluens (ex Stanier 1940; emend. Lewin 1969) Reichenbach 1989 in Persicobacter gen. nov. as Persicobacter diffluens comb. nov. Int J Syst Bacteriol 47, 220-223.

Nedashkovskaya, O. I., Suzuki, M., Vysotskii, M. V. \& Mikhailov, V. V. (2003a). Reichenbachia agariperforans gen. nov., sp. nov., a novel marine bacterium in the phylum Cytophaga-FlavobacteriumBacteroides. Int J Syst Evol Microbiol 53, 81-85.

Nedashkovskaya, O. I., Suzuki, M., Vysotskii, M. V. \& Mikhailov, V. V. (2003b). Vitellibacter vladivostokensis gen. nov., sp. nov., a new member of the phylum Cytophaga-Flavobacterium-Bacteroides. Int J Syst Evol Microbiol 53, 1281-1286.

Nedashkovskaya, O. I., Suzuki, M., Vysotskii, M. V. \& Mikhailov, V. V. (2003c). Arenibacter troitsensis sp. nov., isolated from marine bottom sediment. Int J Syst Evol Microbiol 53, 1287-1290.

Nedashkovskaya, O. I., Kim, S. B., Han, S. K. \& 7 other authors (2003d). Mesonia algae gen. nov., sp. nov., a novel marine bacterium of the family Flavobacteriaceae isolated from the green alga Acrosiphonia sonderi (Kütz) Kornm. Int J Syst Evol Microbiol 53, 1967-1971.

Nedashkovskaya, O. I., Kim, S. B., Han, S. K., Rhee, M. S., Lysenko, A. M., Falsen, E., Frolova, G. M., Mikhailov, V. V. \& Bae, K. S. (2004a). Ulvibacter litoralis gen. nov., sp. nov., a novel member of the family Flavobacteriaceae isolated from the green alga Ulva fenestrata. Int J Syst Evol Microbiol 54, 119-123.

Nedashkovskaya, O. I., Kim, S. B., Han, S. K., Lysenko, A. M., Mikhailov, V. V. \& Bae, K. S. (2004b). Arenibacter certesii sp. nov., a novel marine bacterium isolated from the green alga Ulva fenestrata. Int J Syst Evol Microbiol 54, 1173-1176.

Nedashkovskaya, O. I., Suzuki, M., Vancanneyt, M., Cleenwerck, I., Lysenko, A. M., Mikhailov, V. V. \& Swings, J. (2004c). Zobellia amurskyensis sp. nov., Zobellia laminariae sp. nov. and Zobellia russellii sp. nov., novel marine bacteria of the family Flavobacteriaceae. Int J Syst Evol Microbiol 54, 1643-1648.

Nedashkovskaya, O. I., Kim, S. B., Lysenko, A. M., Frolova, G. M., Mikhailov, V. V., Lee, K. H. \& Bae, K. S. (2005). Description of Aquimarina muelleri gen. nov., sp. nov., and proposal of the reclassification of [Cytophaga] latercula Lewin 1969 as Stanierella latercula gen. nov., comb. nov. Int J Syst Evol Microbiol 55, 225-229. 
Reichenbach, H. (1989). Genus I. Cytophaga Winogradsky 1929, $577,{ }^{\mathrm{AL}}$ emend. In Bergey's Manual of Systematic Bacteriology, vol. 3, pp. 2015-2050. Edited by J. T. Staley, M. P. Bryant, N. Pfennig \& J. C. Holt. Baltimore: Williams \& Wilkins.

Saitou, N. \& Nei, M. (1987). The neighbor-joining method: a new method for reconstructing phylogenetic trees. Mol Biol Evol 4, 406-425.

Suzuki, M., Nakagawa, Y., Harayama, S. \& Yamamoto, S. (2001). Phylogenetic analysis and taxonomic study of marine Cytophaga-like bacteria: proposal for Tenacibaculum gen. nov. with Tenacibaculum maritimum comb. nov. and Tenacibaculum ovolyticum comb. nov., and description of Tenacibaculum mesophilum sp. nov. and Tenacibaculum amylolyticum sp. nov. Int J Syst Evol Microbiol 51, 1639-1652.

Tan, T. L. (1997). Biolog metabolic fingerprints for clustering marine oligotrophic bacteria from polar regions. In Microbial Communities - Functional Versus Structural Approaches, pp. 161170. Edited by H. Insam \& A. Rangger. Berlin: Springer.

Tan, T. L., Joiris, C. R., Glansdorff, N. \& Rüger, H.-J. (1999). Dominance of oligotrophic bacteria in surface waters above
Gunnerus and Astrid Ridges, Antarctic Ocean. Arch Hydrobiol Spec Issues Advanc Limnol 54, 237-253.

Vancanneyt, M., Mengaud, J., Cleenwerck, I. \& 7 other authors (2004). Reclassification of Lactobacillus kefirgranum Takizawa et al. 1994 as Lactobacillus kefiranofaciens subsp. kefirgranum subsp. nov. and emended description of L. kefiranofaciens Fujisawa et al. 1988. Int J Syst Evol Microbiol 54, 551-556.

Wayne, L. G., Brenner, D. J., Colwell, R. R. \& 9 other authors (1987), International Committee on Systematic Bacteriology. Report of the ad hoc committee on reconciliation of approaches to bacterial systematics. Int J Syst Bacteriol 37, 463-464.

Wilson, K. (1987). Preparation of genomic DNA from bacteria. In Current Protocols in Molecular Biology, pp. 2.4.1-2.4.5. Edited by F. M. Ausubel, R. Brent, R. E. Kingston, D. D. Moore, J. G. Seidman, J. A. Smith \& K. Struhl. New York: Green Publishing and Wiley-Interscience.

Winogradsky, S. (1929). Études sur la microbiologie du sol - sur la dégradation de la cellulose dans le sol. Ann Inst Pasteur 43, 549633 (in French). 